\title{
NOTE
}

\section{Feeding by the small calanoid copepod Paracalanus sp. on heterotrophic dinoflagellates and ciliates}

\author{
Kentaro Suzuki ${ }^{1, *}$, Yasuo Nakamura ${ }^{2, * *}$, Juro Hiromi $^{1}$ \\ ${ }^{1}$ College of Bioresource Sciences, Nihon University, Kameino, Fujisawa, Kanagawa 252-0813, Japan \\ ${ }^{2}$ National Institute for Environmental Studies, Tsukuba, Ibaraki 305-0053, Japan
}

\begin{abstract}
Feeding of the calanoid copepod Paracalanus sp. on natural populations of heterotrophic (h-) dinoflagellates and ciliates was examined during the summer in the Seto Inland Sea Japan. Paracalanus sp. ingested h-dinoflagellates with clearance rates of 35 to $146 \mathrm{ml}$ ind. ${ }^{-1} \mathrm{~d}^{-1}$, comparable to those for autotrophic (a-) dinoflagellates. Feeding rates of the copepod on h-dinoflagellates $\left(0.35\right.$ to $0.93 \mu \mathrm{g} \mathrm{C}$ ind.$\left.^{-1} \mathrm{~d}^{-1}\right)$ were close to, or in some cases exceeded, the basic metabolic demands $\left(0.5 \mu \mathrm{g} \mathrm{C}\right.$ ind.-1 $\left.\mathrm{d}^{-1}\right)$ of the copepod. Ciliates were also ingested by Paracalanus sp., but the corresponding clearance rates (23 to $60 \mathrm{ml}$ ind.-1 $\mathrm{d}^{-1}$ ) were lower than those for h-dinoflagellates. These results, together with data on the abundance/biomass of Paracalanus sp. and h-dinoflagellates in the study area, indicate that the population of Paracalanus sp. can have a significant feeding impact on $\mathrm{h}$-dinoflagellates.
\end{abstract}

KEY WORDS: Copepod - Heterotrophic dinoflagellate Ciliate Predation Paracalanus

Ciliates and heterotrophic (h-) dinoflagellates are now recognized as important consumers of phytoplankton in marine ecosystems (e.g. Sherr \& Sherr 1992, Burkil et al. 1993, Buck \& Newton 1995, Nakamura et al. 1995, 1996). Furthermore, ciliates are also regarded as a link between pico-/nano-sized particles (bacteria, picophytoplankton and nanoflagellates) and metazoans such as copepods (e.g. Sherr \& Sherr 1988, Stoecker \& Capuzzo 1990). From the standpoint of carbon flow through planktonic food webs, it thus becomes inevitable to assess the fate of ciliates and h-dinoflagellates. In this context, studies on the ciliatecopepod trophic link have been conducted over the

\footnotetext{
- Present address: Institute of General Science for Environment, Shin-Nippon Meteorological and Oceanographical Consultant, Riemon, Ohi-gawa, Shida, Shidzuoka 421-0212, Japan

•Addressee for correspondence.E-mail: yasuo@nies.go.jp
}

past 15 yr. They indicated that copepods including 'herbivorous' species ingest ciliates actively and have a significant impact on ciliate populations (e.g. Stoecker \& Capuzzo 1990, Dolan 1991, Sanders \& Wickham 1993, Fessendenn \& Cowells 1994, Froneman et al. 1996, Merrell \& Stoecker 1998). On the other hand, studies on the interactions between h-dinoflagellates and copepods are rather restricted (Jeong 1994, Froneman et al. 1996, Verity \& Paffenhöfer 1996, Nakamura \& Turner 1997)

A calanoid copepod, Paracalanus sp., which has been identified as $P$. parvus (Hirota 1979), but is morphologically more like $P$. quasimodo (J. Hiromi unpubl.), is one of the most abundant copepods in Japanese coastal waters (Liang \& Uye 1996). In the present study, feeding of Paracalanus sp. on ciliates, h-dinoflagellates and phytoplankton species in natural seawater was examined to assess the fate of ciliates and h-dinoflagellates in the Seto Inland Sea, where microprotozoans play important roles in the collapse of phytoplankton blooms (Nakamura et al. 1995, 1996).

Materials and methods. Field monitoring: In summer 1997 (17 July to 11 August), a field survey was conducted at Stn B $\left(34^{\circ} 35^{\prime} \mathrm{N}, 134^{\circ} 30^{\prime} \mathrm{E}, 21 \mathrm{~m}\right.$ depth; see Nakamura et al. 1993) around the Ie-shima Islands, in the Seto Inland Sea, Japan. Monitoring and routine sampling were conducted daily except on 25 and 26 July due to a typhoon. Temporal and vertical changes in water temperature, salinity, nutrients, chlorophyll $a$, and abundance of pico/nanoplankton and netzooplankton are reported elsewhere (Nakamura 1999). Samples for enumeration of ciliates/phytoplankton $(100 \mathrm{ml})$ were taken at 0 and $10 \mathrm{~m}$, fixed with acid Lugol's solution (final conc. $=2 \%$ ), stored at $5^{\circ} \mathrm{C}$ and counted by the Utermöhl method $(10 \mathrm{ml})$ within 1 mo after completion of the survey. Samples for h-dinoflag- 
ellates $(80 \mathrm{ml})$ were also taken from 0 and $10 \mathrm{~m}$, fixed with glutaraldehyde (final conc. $=1 \%$ ), and stained with DAPI (final conc. $=1 \mu \mathrm{g} \mathrm{m} l^{-1}$ ). The stained samples $(20 \mathrm{ml})$ were concentrated onto black Nuclepore filters (pore size $=0.8 \mu \mathrm{m}$ ), and $\mathrm{h}$-dinoflagellates were enumerated by observing the filters using an epifluorescence microscope. Detailed conditions for the enumerations have been summarized in a previous paper (Nakamura et al. 1995). Ciliates and h-dinoflagellates for field monitoring were enumerated for cells with length $>15$ and $>20 \mu \mathrm{m}$, respectively.

Samples for enumeration of copepods $(1000 \mathrm{ml})$ were taken at $0,5,10,15$ and $19 \mathrm{~m}$, concentrated through a $20 \mu \mathrm{m}$ mesh sieve to a volume of $\sim 80 \mathrm{ml}$, fixed with neutralized formalin (final conc. $=5 \%$ ) and observed under a stereo microscope within 5 mo after collection. Copepods (adults and copepodites) were identified and counted, and their prosome lengths (PL) were measured to the nearest $10 \mu \mathrm{m}$ for ail individuais in the samples. PL was converted into carbon weight from the species specific equation given by Uye (1982, 1991). Since the sampling volume in the present study was low (1000 $\mathrm{ml}$ for each depth) in comparison with other studies, only the values averaged over the water column were reported for abundance and biomass.

Feeding experiments: Individuals of Paracalanus sp. for feeding experiments were obtained by gentle vertical tows from $15 \mathrm{~m}$ at Stn B. Adult females of Paracalanus sp. were isolated and preconditioned overnight in filtered seawater $(<100 \mu \mathrm{m}, 1000 \mathrm{ml})$ at the temperature of $15 \mathrm{~m}$ depth $\left( \pm 1^{\circ} \mathrm{C}\right)$. On the following day, filtered surface seawater from Stn B $\left(<100 \mu m_{;} \sim 201\right)$ was prepared on board and brought back to the field laboratory within $10 \mathrm{~min}$. The filtrate ('initial assemblage') was mixed gently and siphoned into 6 bottles (polycarbonate, $1100 \mathrm{ml}$ ), 100 and $80 \mathrm{ml}$ aliquots of the initial assemblage were also fixed with acid Lugol's solution and glutaraldehyde for enumeration of ciliates/phytoplankton and h-dinoflagellates, respectively. Then individuals of Paracalanus sp. were introduced to 3 bottles (15 ind. bottle ${ }^{-1}$ ), while the other bottles served as controls. The bottles were rendered free of air space or bubbles by the use of parafilm, wrapped with black sheeting to suppress algal growth, and suspended at $3 \mathrm{~m}$ depth from the pontoon of the field laboratory for 22.5 h. Following completion of the incubation, the bottles were retrieved and the survival of Paracalanus sp. was confirmed. Then 100 and $80 \mathrm{ml}$ aliquots were taken from each bottle and used for the enumeration of ciliates/phytoplankton and h-dinoflagellates, respectively. These experiments were conducted 4 times.

Each sample for enumeration of $\mathrm{h}$-dinoflagellates $(80 \mathrm{ml}$ with $4 \mathrm{ml}$ of glutaraldehyde solution) was stained with DAPI (final volume $=92 \mathrm{ml}$ ) and filtered through 3 Nuclepore filters $(30 \mathrm{ml} \times 3$; pore size $=$
$0.8 \mu \mathrm{m}$ ) for epifluorescence microscopic enumeration. By observing 3 filters per sample $\left(\sim 100\right.$ fields filter $\left.{ }^{-1}\right)$ at a magnification of $\times 250$, h-dinoflagellates on the filters were counted for size categories of 15 to 20,20 to 40 and $>40 \mu \mathrm{m}$. The countings were conducted within $3 \mathrm{~d}$ after sampling.

Preserved ciliate/phytoplankton samples were concentrated by settling $30 \mathrm{ml}$ of the sample for at least $24 \mathrm{~h}$. The entire settling chamber was enumerated for all aloricate ciliates with size categories of 15 to 20,20 to 40 and $>40 \mu \mathrm{m}$ using an inverted microscope at $\times 200$ magnification. Phytoplankton was enumerated only for dominant species by observation at $\times 200$.

The sizes of ciliates and the dominant phytoplankton species were measured and converted to cell volumes assuming simple geometric cell shapes. Cell volumes of h-dinoflagellates were assumed to be 1760,4800 and $12000 \mu^{3}$ for cells of 15 to 20,20 to 40 and $>40 \mu \mathrm{m}$ (NNakamura el di. 1995), respectiveiy. Phytoplankton cell volume was converted to carbon using Strathmann's (1967) equation, and a conversion factor of $0.15 \mathrm{pg} \mathrm{C} \mathrm{mm}^{-3}$ was used for the estimation of the $\mathrm{C}$-contents of ciliates and h-dinoflagellates (cf. Putt \& Stoecker 1989, Lessard 1991).

Clearance rates (CR) of Paracalanus sp. were calculated using Frost's (1972) equation for prey items whose number in the initial sample exceeded 60 cells, only when the difference in the prey abundance between control and experimental bottles proved significant ( $t$-test, $\mathrm{p}<0.05$ ).

Results and discussion. During the survey period, 4 peaks of chlorophyll $a$ (18 and 27 July, 1 and 11 August) were observed (Fig. 1A); the second peak was due to a surface bloom of an autotrophic (a-) dinoflagellate, Gymnodinium mikimotoi, and the other peaks were due to diatom blooms (cf. Nakamura 1998). Ciliates were dominated by naked oligotrichs throughout the survey period; tintinnids were found only occasionally ( $<5 \%$ of total abundance). The abundance of ciliates (Fig. 1A) was relatively constant at $\sim 10 \mathrm{cells} \mathrm{ml}^{-1}$ during the first half of the survey, then showed a prominent peak on 2 to 3 August, after which it declined rapidly.

Based on the observations of live samples, h-dinoflagellates were dominated by naked gymnodinials such as Gyrodinium dominans $(<40 \mu \mathrm{m})$ and Gyrodinium spirale $(>40 \mu \mathrm{m})$ throughout the survey period. Thecate cells were observed only occasionally $(<10 \%$ of the total abundance). The abundance of h-dinoflagellates was around $\sim 15$ cells $\mathrm{ml}^{-1}$ during the first week of the survey, then showed a prominent peak on 28 July just after the bloom of Gymnodinium mikimotoi (Nakamura 1998; cf. Nakamura et al. 1995). In the second half of the survey, the abundance of h-dinoflagellates decreased to $\sim 5 \mathrm{cells} \mathrm{ml}^{-1}$ (Fig. 1A). 

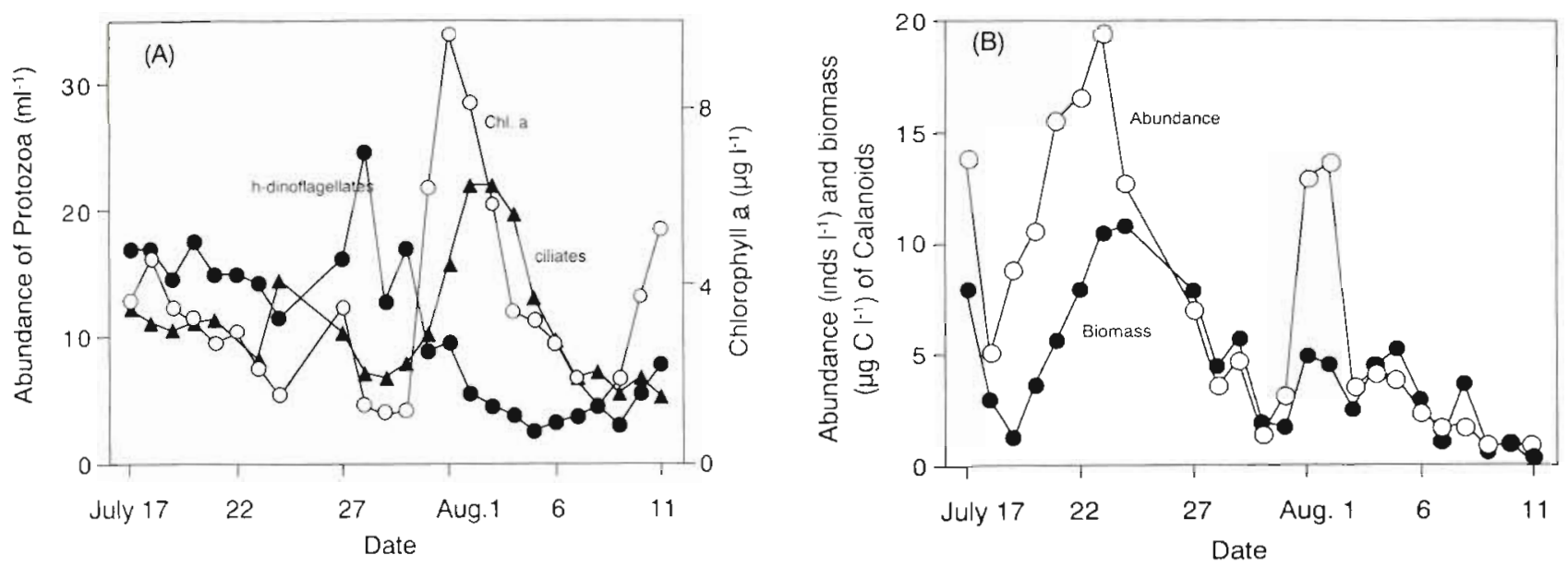

Fig. 1. Field observations. (A) Temporal changes in chlorophyll a (O) averaged over the water column; abundance of heterotrophic dinoflagellates ( ) averaged between 0 and $10 \mathrm{~m}$ depth; and abundance of ciliates ( $\mathbf{\Delta}$ ) averaged between 0 and $10 \mathrm{~m}$ depth. (B) Temporal changes in abundance (O) and biomass ( ) of calanoid copepods (nauplii not included)

Calanoid copepods were composed almost exclusively of Paracalanus sp. throughout the survey period The abundance and biomass of calanoids averaged over the water column showed several peaks and ranged from 0.7 to 19.5 ind. $\mathrm{l}^{-1}$ and 0.3 to 10.8 (temporal average $=4.4) \mathrm{\mu g} \mathrm{Cl}^{-1}$, respectively (Fig. 1B).
Results of the feeding experiments are summarized in Table 1. Paracalanus sp. ingested h-dinoflagellates of all size categories with a CR of 35 to $146 \mathrm{ml} \mathrm{ind} .^{-1} \mathrm{~d}^{-1}$ $\left(n=9\right.$, average $=76 \mathrm{ml}$ ind.$\left.^{-1} \mathrm{~d}^{-1}\right)$; no trends were apparent with a CR as a function of prey cell volume (Fig. 2A). Paracalanus sp. also ingested ciliates with a

Table 1. Paracalanus sp. Feeding experiments conducted in summer 1997. $\mathbf{N}_{\text {int }}$ : initial prey abundance, $\langle$ P $\rangle$ : average of prey biomass in experimental bottles; CR: clearance rate; F: feeding rate; h-dinos: heterotrophic dinoflagellates. ns: not significant

\begin{tabular}{|c|c|c|c|c|c|}
\hline $\begin{array}{l}\text { Expt } \\
\text { (Date and conditions) }\end{array}$ & Prey item & $\begin{array}{l}\mathrm{N}_{\text {int }} \\
\text { (cells } \mathrm{ml}^{-1} \text { ) }\end{array}$ & $\begin{array}{c}<\mathrm{P}> \\
\left(\mu \mathrm{C} \mathrm{I}^{-1}\right)\end{array}$ & $\begin{array}{c}\mathrm{CR} \\
\left(\mathrm{ml} \text { ind.-1 } \mathrm{d}^{-1}\right)\end{array}$ & $\left.\frac{F}{(\mu g C \text { ind. }} .^{-1} d^{-1}\right)$ \\
\hline \multirow[t]{3}{*}{$\begin{array}{l}\text { Expt } 1 \\
19-20 \text { Jul }\left(23.7^{\circ} \mathrm{C}, 31.8 \%\right)\end{array}$} & $\begin{array}{r}\mathrm{H}-\operatorname{dinos}(15-20 \mu \mathrm{m}) \\
(20-40 \mu \mathrm{m})\end{array}$ & $\begin{array}{l}10.5 \\
10.2\end{array}$ & $\begin{array}{l}3.0 \\
6.4\end{array}$ & $\begin{array}{l}63 \pm 8 \\
35 \pm 4\end{array}$ & $\begin{array}{l}0.19 \\
0.22\end{array}$ \\
\hline & Ciliates $(15-20 \mu \mathrm{m})$ & 14.3 & 1.8 & $35 \pm 9$ & 0.06 \\
\hline & $\begin{array}{l}\text { Gymnodinium mikimotoi } \\
\text { Scripsiella sp. }\end{array}$ & $\begin{array}{l}22.0 \\
69.8\end{array}$ & $\begin{array}{l}3.8 \\
5.3\end{array}$ & $\begin{array}{l}47 \pm 21 \\
45 \pm 13\end{array}$ & $\begin{array}{l}0.18 \\
0.23\end{array}$ \\
\hline \multirow[t]{3}{*}{$\begin{array}{l}\text { Expt } 2 \\
23-24 \text { Jul }\left(24.8^{\circ} \mathrm{C}, 31.9^{\circ}, 2\right)\end{array}$} & $\begin{aligned} \text { H-dinos } & (15-20 \mu \mathrm{m}) \\
& (20-40 \mu \mathrm{m}) \\
& (>40 \mu \mathrm{m})\end{aligned}$ & $\begin{array}{r}20.1 \\
10.9 \\
5.4\end{array}$ & $\begin{array}{l}4.0 \\
5.4 \\
5.0\end{array}$ & $\begin{array}{l}45 \pm 7 \\
76 \pm 10 \\
68 \pm 7\end{array}$ & $\begin{array}{l}0.18 \\
0.41 \\
0.34\end{array}$ \\
\hline & $\begin{aligned} \text { Ciliates } & (15-20 \mu \mathrm{m}) \\
& (20-40 \mu \mathrm{m}) \\
& (>40 \mu \mathrm{m})\end{aligned}$ & $\begin{array}{r}10.1 \\
3.1 \\
2.1\end{array}$ & $\begin{array}{l}1.3 \\
1.3 \\
4.2\end{array}$ & $\begin{array}{l}42 \pm 14 \\
30 \pm 16 \\
60 \pm 20\end{array}$ & $\begin{array}{l}0.05 \\
0.04 \\
0.25\end{array}$ \\
\hline & Gymnodinium mikimotoi & 21.3 & 3.3 & $50 \pm 12$ & 0.17 \\
\hline \multirow[t]{3}{*}{$\begin{array}{l}\text { Expt } 3 \\
31 \mathrm{Jul}-1 \text { Aug }\left(24.5^{\circ} \mathrm{C}, 29.5 \%\right)\end{array}$} & $\begin{array}{r}\text { H-dinos }(15-20 \mu \mathrm{m}) \\
(20-40 \mu \mathrm{m})\end{array}$ & $\begin{array}{l}8.3 \\
9.9\end{array}$ & $\begin{array}{l}1.6 \\
4.3\end{array}$ & $\begin{array}{l}61 \pm 4 \\
93 \pm 32\end{array}$ & $\begin{array}{l}0.10 \\
0.40\end{array}$ \\
\hline & Ciliates $(15-20 \mu \mathrm{m})$ & 6.0 & 0.8 & ns & 0.00 \\
\hline & Ceratium fusus & 9.2 & 7.5 & ns & 0.00 \\
\hline \multirow[t]{3}{*}{$\begin{array}{l}\text { Expt } 4 \\
8-9 \text { Aug }\left(25.2^{\circ} \mathrm{C}, 31.1^{\circ}\right)\end{array}$} & $\begin{array}{r}\text { H-dinos }(15-20 \mu \mathrm{m}) \\
(20-40 \mu \mathrm{m})\end{array}$ & $\begin{array}{l}9.4 \\
6.7\end{array}$ & $\begin{array}{l}1.8 \\
1.4\end{array}$ & $\begin{aligned} 85 & \pm 3 \\
146 & \pm 17\end{aligned}$ & $\begin{array}{l}0.15 \\
0.20\end{array}$ \\
\hline & Ciliates $(15-20 \mu \mathrm{m})$ & 8.7 & 1.2 & $23 \pm 18$ & 0.03 \\
\hline & $\begin{array}{l}\text { Scripsiella sp. } \\
\text { Gymnodinium mikimotoi } \\
\text { Ceratium fusus }\end{array}$ & $\begin{array}{l}6.7 \\
2.4 \\
2.9\end{array}$ & $\begin{array}{l}0.4 \\
0.5 \\
1.7\end{array}$ & $\begin{array}{l}98 \pm 72 \\
55 \pm 40 \\
55 \pm 45\end{array}$ & $\begin{array}{l}0.04 \\
0.03 \\
0.09\end{array}$ \\
\hline
\end{tabular}



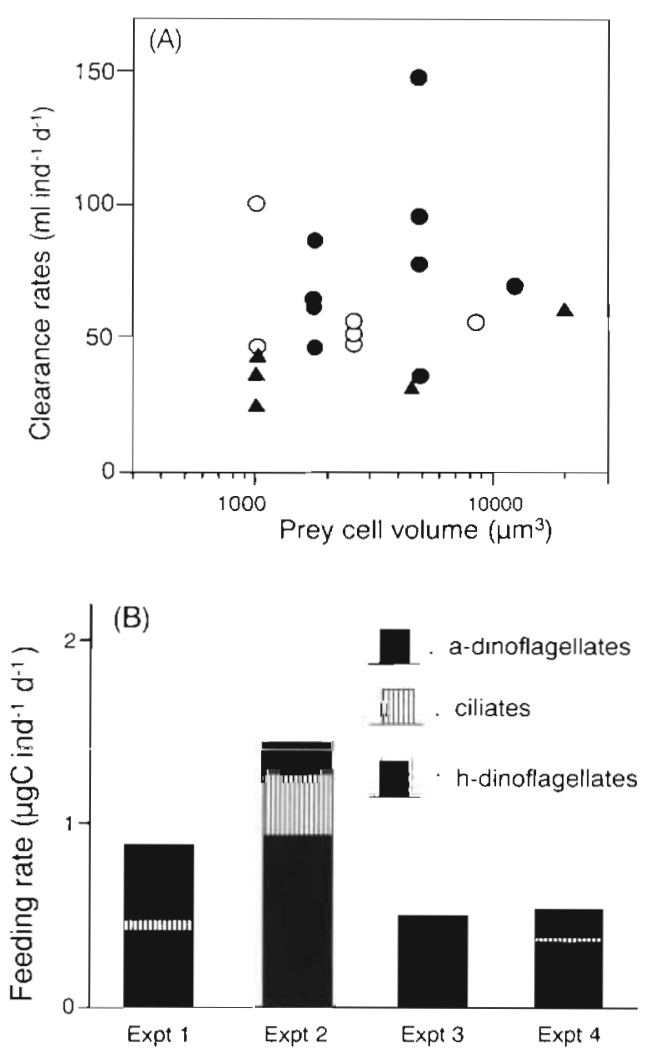

Fig. 2. Paracalanus sp. Feeding experiments. (A) Clearance rates for heterotrophic dinoflagellates (O), autotrophic dinoflagellates (O) and ciliates ( $\triangle$ ) as a function of prey cell volume. (B) Feeding rates on motile prey

CR of 23 to $60 \mathrm{ml} \mathrm{ind.-1} \mathrm{d}^{-1}\left(\mathrm{n}=5\right.$, average $=38 \mathrm{ml}$ ind..$^{-1}$ $\mathrm{d}^{-1}$ ), except for Expt 3, where feeding was insignificant; CR values for ciliates (not including the results in Expt 3) were significantly less than for h-dinoflagellates ( $t$-test, $\mathrm{p}<0.05)$. Although not conclusive, the lower CR values for ciliates may be due to the difference in the swimming mode between h-dinoflagellates and ciliates: in contrast to the smooth and steady motion of h-dinoflagellates, ciliates (dominated by oligotrichs during the survey period) show a jerky motion with a much higher maximum swimming speed. The quick motion of the ciliates might enable them to escape much more easily from the feeding currents created by Paracalanus sp. (cf. Jonsson \& Tiselius 1990), which probably cannct change its feeding mode to 'ambush' predation like Acartia tonsa (Bartram 1980, Kiørboe et al. 1996).

CR values for a-dinoflagellates were in the range 45 to $98 \mathrm{ml}$ ind..$^{-1} \mathrm{~d}^{-1}\left(\mathrm{n}=6\right.$, average $=58 \mathrm{ml}$ ind.$\left.^{-1} \mathrm{~d}^{-1}\right)$ except for a large thecate species, Ceratium fusus, in Expt 3; the difference in the CR values between $h$ - and a-dinoflagellates (except the data for $C$. fusus in Expt 3) was not significant ( $t$-test; $p>0.1$ ). Since there are no differences in the swimming mode between a- and h-dinoflagellates, the comparable values of $C R$ for both groups suggest that Paracalanus sp. does not discriminate prey items based on the presence of the chloroplast

CR values obtained in the present study are higher than those for Paracalanus sp. fed the raphidophicean flagellate Chattonella antiqua (equivalent spherical diameter $=35 \mu \mathrm{m})\left(20 \mathrm{ml}\right.$ ind.$^{-1} \mathrm{~d}^{-1}$; Uye 1986). The carbon specific clearance rates of Paracalanus sp. for hdinoflagellates and ciliates were 33 and $17 \mathrm{ml} \mu \mathrm{g} \mathrm{C}^{-1}$ $\mathrm{d}^{-1}$, respectively (C-content of the copepod $[2.3 \mu \mathrm{g} \mathrm{C}$ ind. $^{-1}$ ] was estimated by the prosome length-body carbon relationship proposed by Uye [1991]). Furthermore, these values were converted to volume specific clearance rates of $2 \times 10^{5}$ and $1 \times 10^{5} \mathrm{~h}^{-1}$ for h-dinoflagellates and ciliates, respectively (carbon:volume conversion factor of $0.16 \mathrm{pg} \mathrm{C} \mu \mathrm{m}^{-3}$ was assumed; Durbin \& Duitbin 1978); these values are comparable to those reported for other copepods (Hansen et al. 1997).

Diatoms such as Chaetoceros lorenzianum and Skeletonema costatum were also grazed by Paracalanus sp. with apparent clearance rates of 24 to $40 \mathrm{ml}$ ind. ${ }^{-1}$ $\mathrm{d}^{-1}$ in some experiments, but not at all in others (data not shown). Since the bottles for feeding experiments were suspended from the pontoon, the obtained values might have been somewhat (but not correctable) underestimated due to sedimentation of the prey. Thus, feeding of Paracalanus sp. on diatoms is not discussed further in the present communication.

During the survey period, the biomass of calanoid copepods (composed almost exclusively of Paracalanus sp.) averaged over the water column was in the range 0.3 to $10.8 \mu \mathrm{g} \mathrm{C} \mathrm{l}^{-1}$ (temporal average $=4.4 \mu \mathrm{g} \mathrm{C} \mathrm{l}^{-1}$ ). Using the assumption that carbon specific clearance rates of Paracalanus sp. for h-dinoflagellates and ciliates are independent of the development stage of the copepod, the population of Paracalanus sp. cleared hdinoflagellates and ciliates with rates of 10 to 360 (temporal average $=150$ ) and 5 to 180 (temporal average $=$ 75) $\mathrm{ml} \mathrm{l}^{-1} \mathrm{~d}^{-1}$, respectively. Thus, when calanoids were abundant in the study area, their feeding impact on microprotozoans, especially h-dinoflagellates, was substantial.

Feeding rates of Paracalanus sp. for h-dinoflagellates were 0.35 to $0.93 \mu \mathrm{g} \mathrm{C}$ ind.$^{-1} \mathrm{~d}^{-1}$; those for motile prey items (a-/h-dinoflagellates plus ciliates) were in the range of 0.50 to $1.44 \mu \mathrm{g} \mathrm{C}$ ind.$^{-1} \mathrm{~d}^{-1}$ (Table 1, Fig. 2B). Since the minimum carbon requirement of Paracalanus sp. is calculated to be $0.5 \mu \mathrm{g} \mathrm{C}$ ind. ${ }^{-1} \mathrm{~d}^{-1}$ (cf. Ikeda 1985, Uye 1991 ; respiratory quotient of 0.8 is assumed), the feeding rates of Paracalanus sp. for h-dinoflagellates were close to or higher than the carbon requirement to maintain basic metabolic activities. This, together with the fact that Paracalanus sp. could have a 
significant impact on the population of h-dinoflagellates (see above), indicates the importance of the trophic link between h-dinoflagellates and copepods for the carbon flow in the study area.

\section{LITERATURE CITED}

Bartram W (1980) Experimental development of a model for the feeding of neritic copepods on phytoplankton. J Plankton Res 3:25-51

Buck KR, Newton J (1995) Fecal pellet flux in Dahob Bay during a diatom bloom: contribution of microzooplankton. Limnol Oceanogr 40:306-315

Burkill PH, Edwards ES, John AWG, Sleigh MA (1993) Microzooplankton and their herbivorous activity in the northeastern Atlantic Ocean. Deep-Sea Res II 40:479-493

Dolan JR (1991) Microphagous ciliates in mesohaline Chesapeake Bay waters: estimates of growth and consumption by copepods. Mar Biol 111:303-309

Durbin EG, Durbin AG (1978) Length and weight relationships of Acartia clausi from Narragansett Bay, RI. Limnol Oceanogr 23:958-969

Fessenden L, Cowles TJ (1994) Copepod predation on phagotrophic ciliate in Oregon coastal waters. Mar Ecol Prog Ser 107:103-111

Froneman PW, Pakhomov EA, Perissinotto R, MCQuaid CD (1996) Role of microplankton in the diet and daily ration of Antarctic zooplankton species during austral summer. Mar Ecol Prog Ser 143:15-23

Frost BM (1972) Effects of size and concentration of food particles on the feeding behavior of the marine planktonic copepod Calanus pacificus. Limnol Oceanogr 17:805-815

Hansen PJ, Biørnsen PK, Hansen BW (1997) Zooplankton grazing and growth: scaling within the $2-2000 \mu \mathrm{m}$ body size range. Limnol Oceanogr 42:687-704

Hirota R (1979) Seasonal occurrence of zooplankton at a definite station off Mukaishima from July of 1976 to June 1977. Publ Amakusa Mar Biol Lab 5:9-17

Ikeda T (1985) Metabolic rates of epipelagic marine zooplankton as a function of body mass and temperature. Mar Biol 85:1-11

Jeong $\mathrm{HJ}$ (1994) Predation effects of the calanoid copepod Acartia tonsa on a heterotrophic dinoflagellate Protoperidinium $\mathrm{cf}$. divergens in the presence of co-occurning red-tide dinoflagellate prey. Mar Ecol Prog Ser 111:87-97

Jonsson PR, Tiselius P (1990) Feeding behaviour, prey detection and capture efficiency of the copepod Acartia tonsa feeding on planktonic ciliates. Mar Ecol Prog Ser 60:35-44

Kiorboe T, Saiz E, Viitasalo M (1996) Prey switching behaviour in the planktonic copepod Acartia tonsa. Mar Ecol Prog Ser 143:65-75

Lessard E (1991) The role of heterotrophic dinoflagellates in diverse environments. Mar Microb Food Webs 5:49-58

Editorial responsibility: John Dolan,

Villefranche-sur-Mer, France
Liang D, Uye S (1996) Population dynamics and production of the planktonic copepods in a eutrophic inlet of the Inland Sea of Japan. III. Paracalanus sp. Mar Biol 127:219-227

Merrell JR, Stoecker DK (1998) Differential grazing on protozoan microplankton by developmental stages of the calanoid copepod Eurytemora affinis Poppe. J Plankton Res 20:289-304

Nakamura Y (1998) Biomass, feeding and production of Noctiluca scintillans in the Seto Inland Sea. J Plankton Res 20:2213-2222

Nakamura Y (1999) Blooms of tunicates Oikopleura spp. and Dolioletta gegenbauri in the Seto Inland Sea, Japan, during summer. Hydrobiol (in press)

Nakamura Y, Turner JT (1997) Predation and respiration by the small cyclopoid copepod Oithona similis: how important is feeding on ciliates and heterotrophic flagellates? J Plankton Res 19:1275-1288

Nakamura Y, Sasaki S, Hiromi J, Fukami K (1993) Dynamics of picocyanobacteria in the Seto Inland Sea (Japan) during summer. Mar Ecol Prog Ser 96:117-124

Nakamura Y, Suzuki S, Hiromi J (1995) Population dynamics of heterotrophic dinoflagellates during a Gymnodinium mikimotoi red tide in the Seto Inland Sea. Mar Ecol Prog Ser 125:269-277

Nakamura Y, Suzuki S, Hiromi J (1996) Development and collapse of a Gymnodinium mikimotoi red tide in the Seto Inland Sea. Aquat Microb Ecol 10:131-137

Putt M. Stoecker DK (1989) An experimentally determined carbon:volume ratio for marine 'oligotrichous' ciliates from estuarine and coastal waters. Limnol Oceanogr 34: 1097-1107

Sanders RW, Wickham A (1993) Planktonic protozoa and metazoa: predation, food quality and population control. Mar Microb Food Webs 7:197-223

Sherr E, Sherr B (1988) Role of microbes in pelagic food webs: a revised concept. Limnol Oceanogr 33:1225-1227

Sherr E, Sherr B (1992) Trophic roles of pelagic protists: phagotrophic flagellates as herbivores. Arch Hydrobiol Beih Ergebn Limnol 37:165-172

Stoecker DK, Capuzzo JD (1990) Predation on protozoa: its importance to zooplankton. J Plankton Res 12:891-908

Strathmann RR (1967) Estimating the organic carbon content of phytoplankton from cell volume or plasma volume. Limnol Oceanogr 12:411-418

Uye S (1982) Length-weight relationships of important zooplankton from the Inland Sea of Japan. J Oceanogr Soc Jpn 38:149-158

Uye S (1986) Impact of copepod grazing on the red-tide flagellate Chattonella antiqua. Mar Biol 92:35-43

Uye S (1991) Temperature-dependent development and growth of the planktonic copepod Paracalanus sp. in the laboratory. Bull Plankton Soc Jpn Spec Vol:627-636

Verity PG, Paffenhöfer G (1996) On assessment of prey ingestion by copepods. J Plankton Res 18:1767-1779

Submitted: October 12, 1998; Accepted: January 24, 1999

Proofs received from author(s): April 9, 1999 